\title{
DAMPAK PEMBALIKAN MODAL DAN THRESHOLD DEFISIT NERACA BERJALAN TERHADAP NILAI TUKAR RUPIAH
}

\author{
M. Noor Nugroho \\ Ibrahim \\ Tri Winarno \\ Meily Ika Permata'
}

\begin{abstract}
This paper studies the effects of foreign capital flows toward the exchange rate of rupiah both in total and across types of capital investment. This paper also analyzes the thresholds of current account deficit which significantly affect the rate of Rupiah. The estimation shows the capital outflow affect the rate of Rupiah to depreciate and is larger than the appreciation pressure of capital inflow (except when invested in Certificate of Bank Indonesia, SBI). Furthermore, the rate of Rupiah is more sensitive on government bond (SUN) than stock or SBI. The yield of this government bond largely affects the probability of the capital reversal. Related to the current account, the estimation shows that after exceeds the threshold of USD980 million monthly deficit or about $2 \%$ of GDP, the exchange rate will depreciate by $12.7 \%$ (m-o-m) with the lag effect of 4 months.
\end{abstract}

Keywords: Capital flows, exchange rate, current account deficit, threshold.

JEL Classification: F31, F32

1 Authors are researcher on Economic Research Bureau, Directorate of Economy Research and Monetary Policy, Bank Indonesia. The views on this paper is solely of the auhtors and do not necessarily represent the views of Bank Indonesia. Corresponding author: nugroho@bi.go.id. 


\section{PENDAHULUAN}

Kinerja sektor eksternal sebuah perekonomian pada umumnya tercermin pada perkembangan neraca pembayaran yang selanjutnya berpengaruh pada nilai tukar. Komponen utama dalam neraca pembayaran adalah transaksi berjalan (Current Account atau CA) dan transaksi modal (Capital and Financial Account atau KA) serta (perubahan) cadangan devisa. Pada saat CA memburuk, seringkali oleh banyak pihak langsung dikaitkan dengan kinerja dan daya saing ekspor yang menurun, dan/atau peningkatan impor yang disebabkan oleh permintaan domestik yang sangat kuat, dan setelah itu, baru melihat faktor-faktor lain seperti perkembangan ekonomi mitra dagang, kandungan impor dalam struktur produksi dan produk ekspor, dan sebagainya. Di sisi lain, KA yang memburuk sering dikaitkan dengan menurunnya aliran modal asing (sudden stop). Di banyak negara dinamika aliran modal asing sering diasosiasikan dengan aliran portfolio investment mengingat aliran modal ini lebih volatile dibandingkan aliran modal lainnya - direct investment dan utang luar negeri - yang lebih stabil. Berbeda dengan CA yang kinerjanya lebih ditentukan oleh faktor fundamental dan faktor domestik, perkembangan KA lebih ditentukan oleh appetite investor asing (portfolio investors). Lebih jauh lagi, perkembangan aliran portfolio investment langsung berpengaruh pada nilai tukar², sehingga dapat menimbulkan ketidakstabilan nilai tukar dan pasar keuangan domestik.

Dalam perkembangannya, kajian yang meneliti keseimbangan eksternal semakin intensif setelah terjadi krisis neraca pembayaran (BOP crisis), seperti krisis Mexico (1992), krisis Asia (1997/98) dan krisis Rusia (1998). Fenomena sudden stop dan capital reversal yang berkaitan dengan defisit CA (CA reversal) juga terjadi banyak negara. Fenomena tersebut biasa ditandai dengan pergerakan aliran modal keluar dalam jumlah yang cukup besar, sedangkan aliran modal masuk terbatas. Ketidakseimbangan aliran modal keluar dan masuk dalam suatu perekonomian, secara langsung berdampak pada nilai tukar. Pada saat terjadi aliran modal keluar dengan jumlah yang jauh lebih besar dari aliran modal masuk, berdampak pada permintaan valuta asing yang meningkat tajam, sehingga nilai tukar terdepresiasi. Pada tahapan berikutnya, suddent stop tersebut dapat berdampak pada kinerja transaksi berjalan. Dari studi yang dilakukan oleh Edwards (2004) terhadap 157 negara dalam periode 1970-2001, terdapat 5,6\% kejadian sudden stop dan 11,8\% CA reversal. Dari sejumlah kejadian tersebut, secara umum dapat ditangkap bahwa fenomena kedua hal tersebut saling berkaitan. Dalam paper tersebut, diungkapkan bahwa dari total sejumlah 2.228 pengamatan, 46,1\% yang mengalami kejadian sudden stop juga menghadapi CA reversal.

Fenomena sudden stop yang didefinisikan sebagai turunnya aliran masuk bersih modal asing dalam jumlah yang besar juga pernah terjadi di Indonesia yaitu dalam beberapa periode setelah krisis 1997/98. Tingginya tekanan arus modal keluar, menyebabkan permintaan valas

2 Pengaruh kinerja CA cenderung tidak berdampak langsung pada nilai tukar oleh karena devisa hasil ekspor tidak langsung dikonversi di pasar valas dan kebutuhan valas untuk impor tidak dipenuhi dengan membeli valas di pasar valas pada saat pembayaran akan dilakukan, namun dapat dibeli bertahap pada saat level nilai tukar kondusif. 
yang jauh lebih besar dari penawaran menyebabkan rupiah mengalami tekanan depresiasi. Pada beberapa periode sudden stop tersebut, BI menerapkan bauran kebijakan termasuk diantaranya adalah intervensi valas dalam jumlah yang cukup besar sehingga tercermin dari penurunan cadangan devisa.

Paska krisis global 2008, pola aliran dana investor global mengarah pada negara berkembang yang masih tumbuh cukup tinggi ditopang oleh permintaan domestik yang kuat. Namun demikian, proses pemulihan ekonomi negara maju yang penuh ketidakpastian telah menjadikan kondisi pasar keuangan sangat rentan terhadap berbagai sentimen negatif. Pasar keuangan akan bergejolak setiap kali indikator risiko global memburuk. Bagi negara berkembang penerima aliran modal asing, hal ini berimplikasi pada aliran modal asing yang semakin volatile. Volume aliran modal asing yang semakin besar dan semakin volatile tersebut mengakibatkan instabilitas nilai tukar dan harga aset keuangan.

Indonesia sebagai salah satu negara berkembang yang survive dari krisis 2008 dalam arti menjadi satu dari sedikit negara yang tetap tumbuh perekonomiannya setelah krisis juga mengalami hal yang sama. Aliran modal asing ke Indonesia meningkat cukup tajam. Aliran modal masuk pernah mencapai lebih dari USD26,6 juta (USD13,2 juta diantaranya merupakan portofolio investment) pada tahun 2010. Aliran modal tersebut mendorong apresiasi rupiah sebesar 12,5\% ke level rata-rata Rp9.080 per US dollar. Sementara itu, harga SUN melonjak yang tercermin pada penurunan yield SUN tenor 10 tahun dari 10,07\% di akhir 2009 ke level terendah sekitar 7,01 pada Oktober 2010 dan ditutup di level 7,83 di Desember 2010. Indeks harga saham juga melonjak dari level 2.534 di akhir 2009 ke level 3.703 di akhir 2010.

Meskipun secara umum mengalami net inflows, pada beberapa periode di 2010 juga terjadi capital reversal, misalnya pada bulan Mei dimana terjadi net outflows cukup besar mencapai USD4,8 miliar, dan pada bulan November dengan net outflows sebesar USD865 juta. Sudden reversa/ tersebut pada umumnya terjadi akibat negative sentiment di negara maju yang sedang berupaya keluar dari krisis. Sudden reversal juga terjadi pada paruh kedua 2011 (dengan net outflows sebesar USD11,9 miliar) dan pertengahan 2012 (USD2,9 miliar) dimana secara keseluruhan berdampak signifikan pada nilai tukar.

Di sisi lain, belum pulihnya AS dan EU dari krisis serta ikut melemahnya perekonomian Jepang berdampak pada menurunnya kinerja ekspor Indonesia. Sebaliknya, permintaan domestik yang masih kuat mendorong impor tetap tumbuh tinggi. Akibatnya, CA memburuk dan bahkan menjadi defisit sejak triwulan IV 2011. CA defisit yang membesar juga berdampak makin signifikan pada nilai tukar sebelumnya pada saat CA defisit relatif rendah tidak berdampak signifikan pada nilai tukar.

Mengingat aliran modal (kinerja KA) dan kinerja CA dapat mempengaruhi pergerakan nilai tukar rupiah, maka perlu dilakukan penelitian yang lebih mendalam mengenai pengaruh aliran modal dan kinerja CA terhadap nilai tukar. Terlebih, pergerakan nilai tukar pada gilirannya juga akan mempengaruhi inflasi yang menjadi tugas utama Bank Indonesia. Aspek lain yang 
juga menjadi pertimbangan adalah pengaruh aliran modal asing pada pengelolaan moneter dan stabilitas sistem keuangan.

Paper ini mengukur pengaruh aliran modal asing terhadap nilai tukar rupiah, baik secara total maupun menurut outlet investasinya, yaitu SUN, SPN, SBI dan saham. Lebih jauh paper ini mengukur pengaruh CA balance terhadap nilai tukar rupiah, serta menguji apakah terdapat threshold CA balance yang menyebabkan dampak CA balance menjadi sangat besar terhadap nilai tukar rupiah.

Bagian kedua dari paper ini menguraikan teori dan studi literatur yang membahas dampak pergerakan arus modal lintas negara. Bagian ketiga mengulas data, model empiris, dan teknik estimasi yang digunakan. Bagian keempat menyajikan analisa deskriptif, hasil estimasi, dan pembahasan; sementara bagian kelima menyajikan kesimpulan dan implikasi kebijakan dari penelitian ini.

\section{TEORI}

Teori dasar terkait open economy adalah Mundell-Flemming model, yang memadukan antara internal dan external balance. Internal balance adalah keseimbangan antara kurva IS dan LM, dimana IS merupakan expenditure curve $(\mathrm{Y}=\mathrm{C}+\mathrm{I}+\mathrm{G}+\mathrm{NX})$ dan LM merupakan kurva money riil (M/P). Sementara external balance ditunjukkan oleh keseimbangan balance of payment dimana total current dan capital account $=0$.

Keseimbangan internal merupakan perpaduan dari keseimbangan pasar barang dan pasar uang. Kurva IS atau keseimbangan pasar barang merupakan akumulasi dari persamaan konsumsi, investasi, pemerintah, dan ekspor neto. Persamaan konsumsi sendiri merupakan fungsi dari disposable income, dan tingkat suku bunga riil dikurangi ekspektasi inflasi. Sementara investasi merupakan fungsi dari pendapatan dan tingkat suku bunga nominal. Ekspor neto merupakan fungsi dari nilai tukar, pendapatan domestik, dan pendapatan mitra dagang. Keseimbangan pasar uang merupakan fungsi dari pendapatan dan tingkat suku bunga riil.

Fungsi konsumsi diberikan sebagai: $C=C[Y-T, r-E(\pi)]$. Fungsi investasi: I $\left.=I\left[i-E(\pi), Y{ }_{-1}\right)\right]$; Fungsi net export: $N X=N X\left(e, Y, Y^{*}\right)$; dan fungsi pasar uang: $M / P=f(Y, r)$. Sementara pengeluaran pemerintah merupakan faktor otonomus $(\mathrm{G}=\mathrm{G})$. 


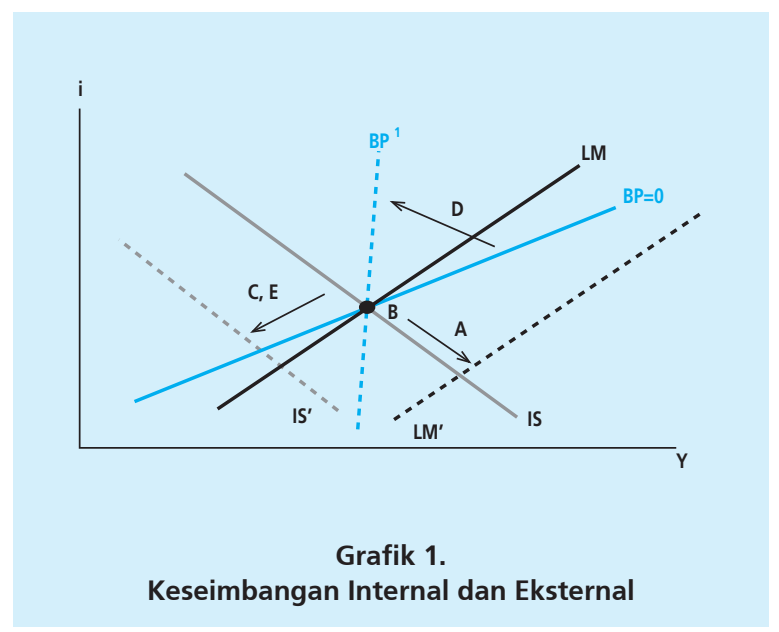

Keseimbangan internal dan eksternal tersebut ditunjukkan dengan titik B pada Grafik 1 di atas yang merupakan pertemuan antara IS, LM, dan BOP=0. Kebijakan bank sentral untuk menambah uang beredar akan menggeser kurva LM ke LM'. Atau dengan fenomena capital inflow, aliran modal yang masuk ke negara berkembang menyebakan permintaan mata uang domestik meningkat. Hasilnya adalah pada poin A, dimana tingkat suku bunga lebih rendah dan output yang diperoleh lebih besar. Beberapa kebijakan yang dapat dilakukan diantaranya apabila inflow tersebut disterilisasi dengan penimbunan cadangan devisa, menyebabkan poin A kembali ke poin $B$, hal ini akan memberikan implikasi periode capital inflow yang lebih panjang akibat tingkat suku bunga yang lebih tinggi. Kebijakan kedua yang mungkin dilakukan apabila bank sentral membiarkan masuknya modal dan tidak melakukan sterilisasi, sehingga terjadi apresiasi nilai tukar. Hal tersebut akan menyebabkan penurunan daya saing dan ekspor. Sehingga menggeser IS dari IS menjadi IS'. Kebijakan lainnya yang mungkin dilakukan adalah melakukan sterilisasi dengan pembatasan aliran modal yang masuk. Hal tersebut menyebabkan efisiensi di dalam negeri yang berkurang, sehingga investasi dalam negeri perlu biaya yang lebih besar (suku bunga lebih tinggi) dibandingkan dari luar negeri yang menawarkan biaya lebih rendah.

Terkait dengan keseimbangan eksternal, nilai tukar dalam sistem nilai tukar mengambang akan ditentukan oleh interaksi antara supply dan demand sebagaimana teori permintaan dan penawaran. Permintaan adalah sejumlah barang atau jasa yang bersedia dibeli oleh konsumen pada berbagai level harga dimana semakin tinggi harganya akan semakin sedikit barang atau jasa yang bersedia dibeli oleh konsumen. Sebaliknya, penawaran adalah jumlah barang atau jasa yang bersedia dijual oleh produsen atau pedagang kepada konsumen pada berbagai level harga. Berbeda dengan sisi permintaan, jumlah barang atau jasa yang ditawarkan penjual berbanding lurus dengan harganya: semakin tinggi harga, semakin banyak barang yang ditawarkan oleh penjual barang dimaksud. Pertemuan antara permintaan dan penawaran barang yang diikuti dengan pertukaran atau transaksi perdagangan adalah yang dikenal dengan pasar. 
Pasar berada dalam kondisi ekuilibrium apabila interaksi antara sisi permintaan dan sisi penawaran menghasilkan satu harga keseimbangan pada kuantitas permintaan dan penawaran tertentu. Pasar valuta asing (valas) merupakan salah satu bentuk pasar dimana komoditi yang diperdagangkan adalah valas, seperti dolar AS, euro, yen Jepang, dan sebagainya. Interaksi antara permintaan dan penawaran valas dalam pembentukan harga valas atau nilai tukar dapat diilustrasikan melalui grafik di bawah.

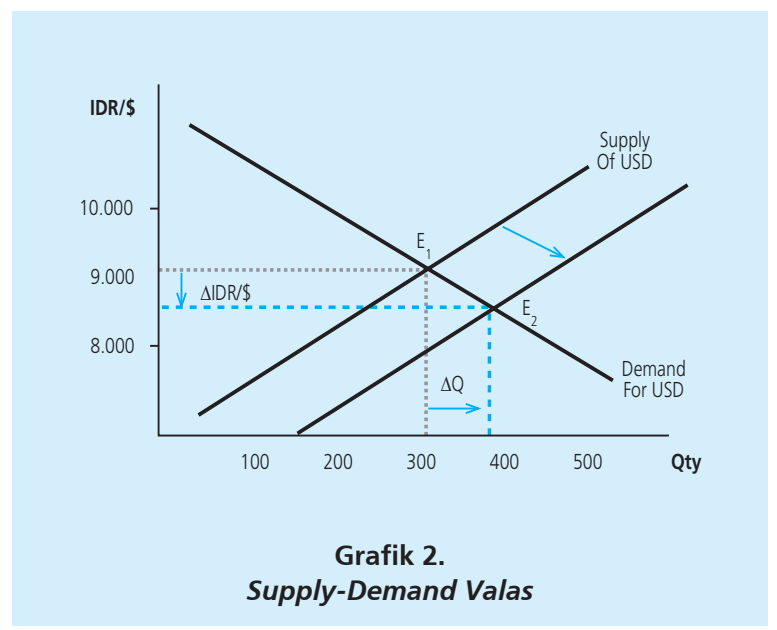

Korelasi negatif antara permintaan mata uang dolar AS dengan nilai tukar rupiah terhadap dolar AS (IDR/\$) sebagai harga dari dolar AS digambarkan oleh kurva 'Demand for USD'. Semakin tinggi nilai tukar (nilai dolar AS meningkat atau semakin mahal) akan men-discourage permintaan sehingga jumlah permintaan akan dolar AS menurun. Sebaliknya, korelasi searah antara nilai tukar dan penawaran dolar AS tercermin pada kurva 'Supply of USD' yang ber-slope positif. Grafik 5 mengilustrasikan ekuilibrium pasar valas tercapai pada titik $\mathrm{E}_{1}$ dimana jumlah dolar $\mathrm{AS}$ yang diminta dan ditawarkan adalah sama (300) pada level nilai tukar keseimbangan Rp9.000/USD. Apabila oleh karena sesuatu hal misalnya ekspor meningkat pasokan dolar AS meningkat, kurva penawaran akan bergeser kekanan sehingga titik keseimbangan bergeser ke poin E2 dengan nilai tukar keseimbangan menjadi Rp8.500/USD (rupiah menguat/dolar AS melemah).

Sejak terjadinya krisis mata uang pada tahun 1990-an, para ekonom telah memusatkan perhatian pada perilaku aliran modal global. Sejumlah penelitian menunjukan bahwa dalam era globalisasi sudden capital reversal atau sudden stop memberikan dampak negatif terhadap perekonomian yang ditinggalkannya. Menurut beberapa ekonomi (Dornbusch, Goldfajn dan Valdes, 1995) sudden capital reversal juga berdampak pada terjadinya pembalikan Current Account (CA) dan proses penyesuaian ekonomi yang mahal. Sebagian besar krisis ekonomi yang terjadi di emerging market dewasa ini ditandai oleh terjadinya sudden capital reversal (Calvo 1998) yang diikuti oleh menurunnya output secara signifikan. 
Edwards (2004) melakukan penelitian dengan menggunakan data panel guna menjawab fenomena dampak CA reversal terhadap kinerja perekonomian. Hasil kajian tersebut menyimpulkan bahwa pembalikan CA berpotensi terjadi apabila defisit CA mencapai 4\% dari GDP. Selain disebabkan oleh defisit CA yang tinggi, pembalikan CA juga dipengaruhi oleh faktor-faktor lain seperti kondisi utang luar negeri, pertumbuhan kredit domestik, dan volatilitas aliran modal asing di suatu negara atau wilayah.

Sula (2008) melakukan penelitian dengan menggunakan metode probit dan data panel guna mengetahui faktor penyebab utama terjadinya sudden capital reversal. Ditengarai penyebab utama terjadinya sudden capital reversal adalah tingginya capital inflows pada periode sebelumnya (sekitar satu hingga tiga tahun sebelumnya), serta komposisi capital inflows yang didominasi oleh non FDI.

Kaminsky, Lizondo, dan Reinhart (1998) membangun model krisis mata uang dengan mengamati beberapa variabel yang melampaui threshold tertentu, dimana diantaranya variabelnya adalah sudden capital outflows. Disamping itu, cadangan devisa yang tidak mencukupi kebutuhan tiga bulan impor serta defisit CA lebih dari 5\% GDP akan dapat memicu terjadinya currency crisis. Sementara itu, Frankel dan Rose (1996) mengembangkan suatu metode untuk memberikan sinyal awal akan terjadinya krisis nilai tukar dengan menggunakan metode probit untuk negara berkembang. Mereka menyimpulkan bahwa sudden stop capital inflows serta komposisi utang luar negeri merupakan variabel yang mengarah pada currency crisis.

Sachs, Tornell dan Velasco (1996) melakukan penelitian dengan menggunakan panel data untuk periode tahun 1995, menganalisa terjadinya currency crisis yang dikenal dengan 'tequila effect' setelah krisis Meksiko. Kajian tersebut mengemukakan bahwa faktor penyebab krisis diantaranya adalah sistem perbankan yang lemah, nilai tukar yang overvalued, serta rendahnya cadangan devisa.

Penelitian lain yang menganalisis threshold suatu variabel bebas dilakukan oleh Kan dan Senhaji (2001) dengan menggunakan data panel. Mereka menemukan nilai threshold inflasi yang masih kondusif untuk pertumbuhan ekonomi sebesar 1-3 persen untuk negara maju dan 11-12 persen untuk negara berkembang.

Terkait dengan trade balance, khususnya ekspor, Stahn (2006) telah melakukan riset tentang ekspor impor Jerman baik ke negara-negara Uni Eropa lain maupun di luar Uni Eropa (khususnya ke Amerika Serikat) dengan menggunakan metode ECM. Variabel yang digunakan meliputi variabel harga REER dan total sales deflator sebagai price competitiveness, serta ekspor regional yang menjadi tujuan ekspor Jerman sebagai proksi permintaan produk ekspor Jerman. Hasil estimasinya menunjukkan bahwa baik variabel harga maupun permintaan barang ekspor berpengaruh signifikan terhadap ekspor Jerman.

Chinn dan Prasad (2003) telah melakukan kajian tentang faktor-faktor yang berpengaruh terhadap CA dengan menggunakan data negara maju dan negara berkembang dengan periode 
sampel antara 1971-1995. Khususnya untuk negara berkembang, Chin dan Prasad menemukan bahwa surplus anggaran pemerintah, posisi net foreign assets, dan votalitas perdagangan berkorelasi erat dengan CA balance.

Calderon et al (2000) meneliti CA deficit di 44 negara berkembang dengan rentang waktu 1966 sampai dengan 1995. Kajian tersebut menemukan bahwa (i) semakin tinggi pertumbuhan ekonomi suatu negara berkembang cenderung akan semakin tinggi defisit CA yang terjadi, (ii) semakin tinggi pertumbuhan ekonomi suatu negara maju cenderung akan semakin rendah defisit CA yang dialaminya, (iii) semakin tinggi tingkat tabungan akan semakin rendah defisit CA yang terjadi, (iv) apresiasi nilai tukar riil meningkatkan defisit CA, dan (v) tingkat bunga internasional yang semakin rendah mengarah pada peningkatan defisit CA.

Sahminan et al (2009) telah melakukan penelitian tentang determinan CA Indonesia serta dinamikannya dengan menggunakan data tahunan rentang waktu 1993 sampai dengan 2008. Tingkat konsumsi, nilai tukar riil dan investasi merupakan faktor-faktor yang mampu menjelaskan fluktuasi CA di Indonesia. Disamping itu, dengan menggunakan intertemporal approach, kajian tersebut juga menemukan bahwa fluktuasi CA Indonesia konsisten dengan fluktuasi CA optimalnya.

Paper ini mencoba memberikan kontribusi pada literatur keilmuan yang terkait dengan pengaruh fenomena sudden capital reversal dan CA pada nilai tukar rupiah pada periode paska krisis keuangan global 2008. Bagian selanjutnya akan menguraikan data dan model empiris yang akan diestimasi.

\section{METODOLOGI}

\subsection{Model Empiris}

Teori permintaan dan penawaran menunjukkan bahwa kenaikan (penurunan) harga barang akan menurunkan (menaikkan) permintaan atas barang tersebut, namun di sisi lain akan meningkatkan (menurunkan) pasokan barang tersebut. Pasar valuta asing dengan mata uang asing sebagai komoditas yang diperdagangkan dan nilai tukar sebagai harga mata uang asing yang dinilai dengan mata uang domestik juga tunduk pada teori permintaan dan penawaran valas. Kenaikan harga US dollar terhadap rupiah (depresiasi rupiah atau ditunjukkan oleh kenaikan level nilai tukar) akan menurunkan permintaan US dollar, namun meningkatkan penawarannya, demikian juga sebaliknya. Hal ini dapat ditunjukkan pada persamaan-persamaan (reduced form) berikut:

Persamaan penawaran valas:

$$
Q_{t}^{S}=a_{0}+a_{1} S_{t}+a_{2} X_{i t}+u_{t}
$$


Persamaan permintaan valas:

$$
Q_{t}^{D}=b_{0}-b_{1} S_{t}+b_{2} X_{i t}+v_{t}
$$

dimana $Q_{t}^{s}$ dan $Q_{t}^{D}$ adalah pasokan dan permintaan valas, $S_{t}$ adalah nilai tukar (dengan kuotasi standar mata uang domestik per US dollar), dan $X_{i t}$ adalah variabel determinan lainnya.

Keseimbangan pasar tercapai pada harga keseimbangan $S_{t}$ dan pada kondisi $Q_{t}^{s}=Q^{D}$. Namun dalam pasar valas dimana bank berfungsi sebagai market maker bank menentukan kurs jual dan kurs beli maka permintaan dan penawaran valas yang dihadapi bank tidak selalu sama $\left(Q_{t}^{s} \neq Q^{D}\right)$. Ekses permintaan atau pasokan tersebut akan diserap oleh bank. Oleh karena bank cenderung bersifat risk averse dan bank dibatasi ketentuan net open position, maka ekses tersebut cenderung minimal atau terbatas. Untuk menekan ekses tersebut bank dapat mengubah kurs jual/beli yang ditawarkan ke nasabahnya. Dengan kondisi tersebut, keseimbangan pasar valas perbankan dapat direpresentasikan oleh persamaan berikut [(1)-(2)]:

$$
Q_{t}^{S}-Q_{t}^{D}=a_{0}-b_{0}+\left(a_{1}+b_{1}\right) S_{t}+\left(a_{2}-b_{2}\right) X_{i}+u_{t}-v_{t}
$$

Dengan mengisolasi $S_{t}$ diperoleh persamaan:

$$
S_{t}=\frac{\left(b_{0}-a_{0}\right)}{\left(a_{1}+b_{1}\right)}-\frac{1}{\left(a_{1}+b_{1}\right)}\left(Q_{t}^{S}-Q_{t}^{D}\right)+\left(\frac{\left(a_{2}-b_{2}\right)}{\left(a_{1}+b_{1}\right)}\right) X_{i}+\left(v_{t}-u_{t}\right)
$$

dan menyederhanakan koefisien-koefisiennya menjadi:

$$
S_{t}=c_{0}-c_{1}\left(Q_{t}^{S}-Q_{t}^{D}\right)+c_{2} X_{i t}+e_{t}
$$

Pasokan valas neto $\left(Q_{t}^{S}-Q_{t}^{D}\right)$ dalam sistem perekonomian terbuka dapat bersumber dari transaksi perdagangan internasional (ekspor-impor) dan aliran modal antar negara. Seluruh transaksi tersebut tercatat pada Current Account (CA) dan Capital and Financial Account (FA) di neraca pembayaran.

$$
S_{t}=c_{0}-c_{1} C A_{t}-c_{2} F A_{t}+c_{3} X_{i t}+e_{t}
$$

Paper ini memfokuskan kajian pada dampak capital reversal pada nilai tukar rupiah. Oleh karena itu, estimasi akan dilakukan menggunakan persamaan 6 dan FA didefinisikan sebagai aliran modal jangka pendek (hot money) ${ }^{3}$ dengan beberapa modifikasi untuk melihat beberapa hal yang krusial, yaitu:

3 Aliran modal jangka pendek mencakup aliran investasi asing pada SUN, saham dan SBI, serta sebagian (diasumsikan sebesar 50\%) dari aliran utang luar negeri. 
- Pengaruh asimetrik antara capital inflows dan capital outflows: FA dipisahkan menjadi outflows dan inflows;

$$
S_{t}=c_{0}-c_{1} F A_{-} I N_{t}-c_{2} F A_{-} O U T_{t}+c_{3} X_{i t}+e_{t}
$$

- Pengaruh reversal yang bersumber dari divestasi asing pada SUN: FA dipisahkan menjadi investasi/divestasi asing pada SUN dan aliran modal lainnya;

$$
S_{t}=c_{0}-c_{1} S U N_{t}-c_{2}\left(F A_{t}-S U N_{t}\right)+c_{3} X_{i t}+e_{t}
$$

- Pengaruh reversal yang bersumber dari divestasi asing pada saham: FA akan dipisahkan menjadi investasi/divestasi asing pada saham dan aliran modal lainnya;

$$
S_{t}=c_{0}-c_{1} \text { Stock }_{t}-c_{2}\left(F A_{t}-\text { Stock }_{t}\right)+c_{3} X_{i t}+e_{t}
$$

- Pengaruh reversal yang bersumber dari divestasi asing pada saham: FA akan dipisahkan menjadi investasi/divestasi asing pada SBI dan aliran modal lainnya;

$$
S_{t}=c_{0}-c_{1} S B I_{t}-c_{2}\left(F A_{t}-S B I_{t}\right)+c_{4} X_{i t}+e_{t}
$$

- Pengaruh reversal yang bersumber dari divestasi asing pada saham: FA akan dipisahkan menjadi investasi/divestasi asing pada SPN dan aliran modal lainnya;

$$
S_{t}=c_{0}-c_{1} S P N_{t}-c_{2}\left(F A_{t}-S P N_{t}\right)+c_{4} X_{i t}+e_{t}
$$

Dalam estimasi model di atas, variabel aliran modal asing yang diinvestasikan SUN, saham, SBI dan SPN akan diestimasi dalam 3 alternatif yaitu dalam bentuk (i) aliran bersih atau neto (inflows dikurangi outflows), (ii) dalam bentuk gross inflows dan outflows (dipecah menjadi 2 variabel), serta (iii) dalam bentuk gross outflows saja. Hal ini dimaksudkan untuk melihat secara spesifik pengaruh outflows dari berbagai outlet investasi tersebut yang dapat dianggap sebagai bagian dari capital reversal.

Selain melihat pengaruh sudden capital reversal terhadap nilai tukar, persamaan 6 juga mencoba melihat pengaruh kinerja CA terhadap nilai tukar, terutama difokuskan pada upaya menentukan threshold CA defisit yang dapat memicu terjadinya depresiasi nilai tukar secara signifikan.

Untuk melengkapi penelitian ini juga akan diestimasi probabilitas terjadinya sudden stop yang dipengaruhi oleh push (luar negeri) dan pull factors (dalam negeri)

$$
\text { Reversal }_{t}=\Phi\left[c_{0}+c_{1} D J I A_{t}+c_{2} I H S G_{t}+c_{3} S U N_{\text {yield }_{t}}+c_{4} V_{I X}+e_{t}\right.
$$


dimana $\Phi$ adalah fungsi kumulatif distribusi normal, DJIA adalah indeks harga saham di AS, IHSG adalah indeks harga saham gabungan di Indonesia, SUN $N_{\text {yield }}$ adalah return dari investasi pada SUN, dan VIX adalah indeks volatilitas yang mencerminkan faktor risiko. DJIA dan VIX

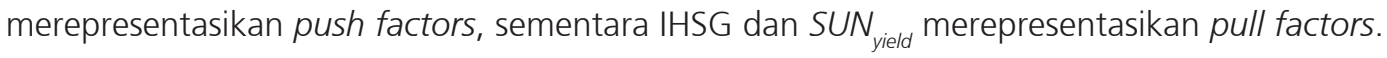
Sementara itu, data yang digunakan dalam estimasi adalah data bulanan dengan periode sampel 2008 - Juni 2012 dimana terjadi beberapa episode sudden capital reversal.

\subsection{Teknik Estimasi}

Dalam melakukan estimasi pengaruh CA terhadap nilai tukar, dilakukan estimasi untuk menentukan suatu level threshold dimana apabila CA memburuk dan melewati nilai threshold tersebut maka akan berdampak signifikan pada nilai tukar rupiah. Untuk mencari threshold level CA dan mengestimasi pengaruhnya ke nilai tukar tersebut digunakan pendekatan nonlinear model threshold autoregressive (TAR).

TAR merupakan suatu regime swithing model yang memungkinkan suatu variabel berperilaku berbeda. Secara umum, besarnya threshold seringkali tidak diketahui dan harus diestimasi secara bersamaan dengan parameter lainnya. Model TAR juga mengakomodasi adanya kemungkinan bahwa lamanya adjustment process untuk terjadinya perubahan rejim memerlukan lebih dari satu periode waktu $(d)$. Nilai $d$ biasa disebut sebagai delay paramater.

Enders (2004)4 dan Chan (1993) memberikan panduan untuk mendapatkan nilai threshold yang super konsisten. Beberapa syarat yang harus dipenuhi adalah :

1. Threshold haruslah terletak dalam range pengamatan.

2. Mengestimasi TAR model untuk berbagai level threshold dan menyimpan nilai sum of squared residuals (SSR) untuk setiap hasil estimasi tersebut berdasarkan asumsi bahwa model dengan nilai threshold yang paling mendekati kenyataan akan mempunyai SSR atau varianster kecil. Alternatif lainnya, model terbaik dipilih berdasarkan nilai Akaike Information Criterion (AIC) dan Schwarz Bayesian Criteria (SBC) terkecil.

Metode threshold autoregressive (TAR) tersebut diaplikasikan ke persamaan nilai tukar:

$$
\begin{aligned}
\Delta e_{t}=\left(\alpha_{0}+\right. & \left.\sum_{i=0}^{k} \alpha_{1 i} L C A_{t-i}\right)\left(1-I_{t-d}\right)+\left(\beta_{0}+\sum_{i=0}^{k} \beta_{1 i} L C A_{t-i}\right)\left(I_{t-d}\right) \\
& +\sum_{i=0}^{l} \gamma_{i} \Delta I R D_{t-i}+\sum_{i=0}^{m} \delta_{i} \Delta R I S K_{t-i}+\sum_{i=1}^{n} \theta_{i} \Delta e_{t-i}+u_{t}
\end{aligned}
$$

4 Walter Enders. 2004. Applied Econometric Time Series. Wiley. 
yang merupakan representasi dari :

$$
\begin{aligned}
\Delta e_{t}= & \left(\alpha_{0}+\sum_{i=0}^{k} \alpha_{1 i} L C A_{t-i}+\sum_{i=0}^{l} \gamma_{i} \Delta I R D_{t-i}+\sum_{i=0}^{m} \delta_{i} \Delta R I S K_{t-i}+\sum_{i=1}^{n} \theta_{i} \Delta e_{t-i}+u_{t}\right) j i k a I_{t-d}<\gamma \\
& \left(\beta_{0}+\sum_{i=0}^{k} \beta_{1 i} L C A_{t-i}+\sum_{i=0}^{l} \gamma_{i} \Delta I R D_{t-i}+\sum_{i=0}^{m} \delta_{i} \Delta R I S K_{t-i}+\sum_{i=1}^{n} \theta_{i} \Delta e_{t-i}+u_{t}\right) j i k a I_{t-d} \geq \gamma
\end{aligned}
$$

Persamaan di atas, merupakan aplikasi model TAR pada model distributed lag. Pada persamaan di atas, perubahan nilai tukar (depresiasi/apresiasi) merupakan fungsi dari level CA, pergerakaan interest rate differential, pergerakan risiko global dan ekspektasi nilai tukar yang bersifat adaptif. Time lag dari variabel independen diwakili oleh i, sementara time lag dari variabel threshold direpresentasikan oleh $\mathrm{d}$. Variabel I merupakan variabel dummy, dimana I ${ }_{d}=0$ jika level CA lebih kecil daripada threshold $\gamma$, dan $I_{t-d}=1$ jika level CA sama atau lebih besar dibandingkan threshold $\gamma$.

Data yang digunakan adalah data bulanan dari periode 2008:01 sampai dengan 2012:06. Data meliputi logaritma perubahan nilai tukar nomimal $(\Delta \mathrm{e})$; level current account $(L C A)$; perubahan interest rate differential $(\Delta \mathrm{R} D)$; dan perubahan resiko global ( $\Delta \mathrm{RISK})$.

\section{HASIL DAN ANALISIS}

\subsection{Analisa Deskriptif}

\section{Dinamika Neraca Pembayaran Indonesia}

Perkembangan Neraca Pembayaran Indonesia (NPI) bergerak dinamis. Pada era sebelum krisis 1998, CA lebih sering berada dalam area negatif. Sedangkan setelah krisis, sebagian besar periode mencatat surplus (Grafik 3). Perkembangan CA balance dapat menggambarkan struktur ekonomi suatu negara. Berbagai perubahan, baik yang bersifat struktural maupun temporer dapat mempengaruhi CA.

Perubahan struktural biasanya berlangsung secara gradual dan berlangsung dalam waktu yang relatif lama serta lebih banyak terkait dengan perkembangan ekonomi domestik. Sementara perubahan yang bersifat temporer biasanya berdampak relatif cepat pada perkembangan NPI, namun bersifat sementara. Indonesia sebagai negara berkembang dan termasuk dalam small open economy, segala perubahan yang terjadi di pasar internasional (harga komoditas dan volume perdagangan dunia) dapat memberi pengaruh signifikan dan segera pada perkembangan ekonomi domestik termasuk diantaranya adalah perkembangan CA. Pengaruh perubahan eksternal kedalam ekonomi domestik tersebut disebut sebagai transmisi melalui jalur perdagangan. 


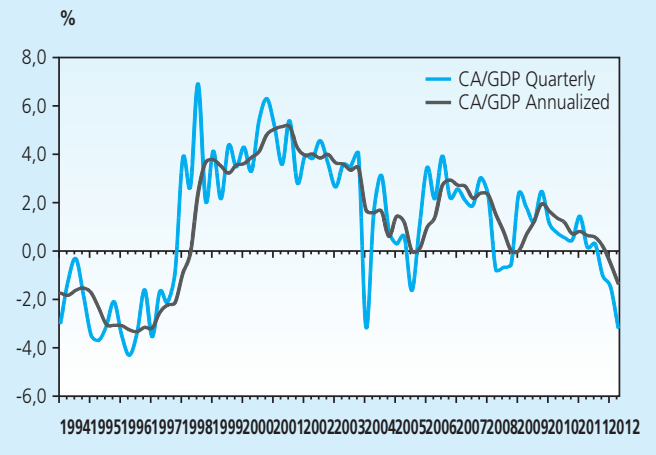

Grafik 3.

Perkembangan Transaksi Berjalan (\% PDB)

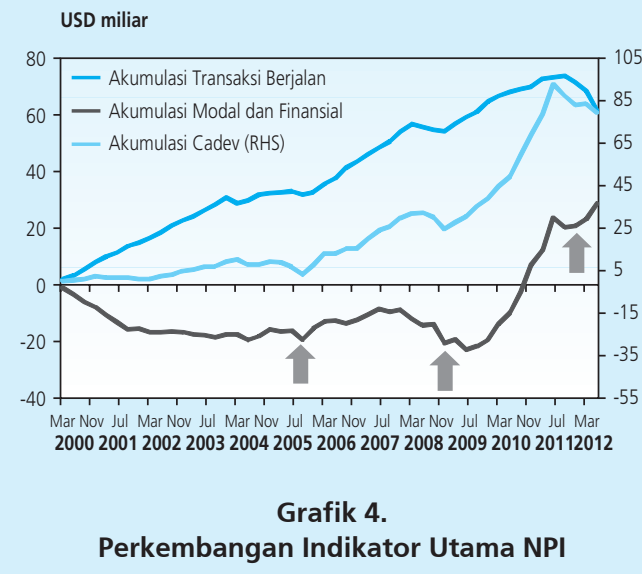

Pada era setelah tahun 2000, atau paska krisis ekonomi 1998, manajemen kebijakan makro relatif berjalan lebih baik. Salah satu perubahan mendasar adalah tata kelola nilai tukar yang mengambang sehingga dapat menangkap sinyal lebih cepat apabila terdapat ketidakseimbangan sisi eksternal. Meskipun demikian, indikator eksternal yang dicerminkan dari NPI mengalami beberapa kali goncangan.

Salah satu faktor ketidakstabilan ekonomi domestik bersumber dari perubahan sistem politik nasional. Ekonomi Indonesia diwarnai ketidakpastian politik sejak reformasi politik 1998. Krisis kepemimpinan nasional yang diwarnai pergantian Presiden melalui Sidang Istimewa membuat kekhawatiran investor asing. Lembaga rating Standard \& Poor's (S\&P) menurunkan rating investasi Indonesia dua kali di bulan Mei dan November 2001. Sementara krisis geopolitik internasional, diwarnai dengan peristiwa 11 September 2001 dan berimbas ke dalam negeri berupa reaksi keras yang menimbulkan situasi yang tidak aman bagi investor asing di dalam negeri. Rentetan ketidakstabilan politik dan ekonomi berimbas pada proses recovery ekonomi sampai dengan tahun 2002.

Dalam beberapa analisis, periode keseimbangan eksternal Indonesia relatif berjalan normal tanpa gejolak politik dan gangguan keamanan secara signifikan adalah periode setelah 2002. Dari sisi statistik dan data NPI juga terdapat penyempurnaan sehingga lebih baik dari periode sebelum tahun 2000-an. Oleh karena itu, periode gejolak keseimbangan eksternal lebih bersumber dari eksternal sehingga mudah dibandingkan. Secara umum, terdapat tiga episode tekanan besar terhadap NPI yaitu pada tahun 2005, 2008, dan 2012.

Gejolak yang terjadi pada tahun 2005 sering disebut juga sebagai mini crisis. Hal ini disebabkan nilai tukar rupiah sempat mengalami penurunan tajam mencapai sekitar Rp11.000 per dolar, sehingga secara tahunan mencatat depresiasi 8,6\% atau lebih tinggi dari gejolak ekonomi 2008. Pemicu utama gejolak di tahun 2005 adalah kenaikan harga komoditas dunia, 
terutama minyak mentah. Respon The Fed yang menaikkan suku bunga sampai 200 bps membuat investor asing merelokasi investasi portofolio masuk ke Amerika. Dengan kenaikan harga minyak mentah dunia, harga BBM domestik juga mengalami kenaikan yang cukup tinggi diatas $100 \%$ sehingga berdampak pada inflasi yang meningkat tajam.

Pada tahun 2008, sumber gejolak juga berasal dari eksternal yaitu harga komoditas yang meningkat dan krisis subprime morgate di Amerika. Pada triwulan akhir 2008, tumbangnya Lehman Brothers menambah rentetan krisis di pasar finansial dunia. Tingginya tekanan keluar modal asing menyebabkan nilai tukar mencapai lebih dari Rp12.000 per US dolar. Sementara untuk tekanan NPI tahun 2012 lebih bersumber pada krisis Eropa, pelemahan ekonomi China dan India. Turunnya harga komoditas non migas dan masih tingginya harga minyak mentah dunia turun berperan pada menurunnya transaksi perdagangan dalam dua triwulan pertama 2012.

Dari ketiga gejolak eksternal tersebut, terlihat dampak gejolak eksternal berdampak pada ekonomi domestik yang dicerminkan dari perkembangan beberapa indikator NPI yang menurun (Grafik 4). Akumulasi transaksi modal dan finansial secara neto mengalami penurunan, sejalan dengan depresiasi nilai tukar rupiah.

\section{Karakteristik Aliran Modal Jangka Pendek ke Indonesia}

Komponen NPI dapat dirinci ke dalam dua komponen besar yaitu neraca transaksi berjalan atau CA dan neraca transaksi modal dan finansial atau KA. Secara struktural, komponen pembentuk CA yang berada pada area surplus adalah transaksi barang (trade balance) dan transaksi transfer. Sedangkan komponen jasa-jasa dan income berada di area defisit (Grafik 5). Peranan keempat komponen tersebut bervariasi tergantung dari nilai nominal. Berdasarkan data rata-rata sejak tahun 2000-2011, komponen CA merupakan komponen terbesar mencapai sekitar 49\%, sementara transaksi transfer hanya 6\%. Komponen yang bergerak di area defisit, yaitu income dan jasa-jasa, masing-masing berkontribusi sebesar 25\% dan 19\%.

Dari neraca jasa-jasa, tipikal negara berkembang seperti Indonesia yang masih lemah daya saing dalam produk jasa menyebabkan transaksi jasa-jasa selalu defisit. Penggunaan jasa angkut dan asuransi yang sangat terkait dalam kegiatan impor, menyebabkan terjadinya penurunan CA yang relatif cepat ketika terjadi lonjakan impor. Sementara itu, transaksi income terkait dengan transfer keuntungan perusahaan asing atas hasil investasi di Indonesia baik dalam bentuk portofolio maupun investasi langsung (PMA). Minat investasi asing yang meningkat pada tahun 2010 dan 2011 menjadi salah faktor utama kenaikan defisit income. 


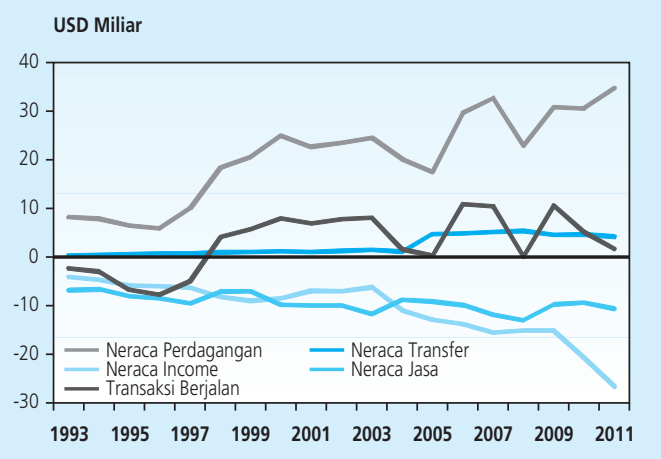

Grafik 5.

Perkembangan Komponen CA Balance

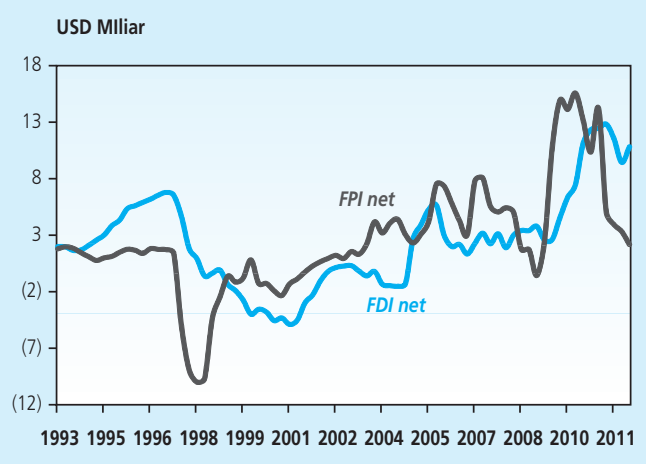

Grafik 6.

Perkembangan Transaksi Portofolio dan PMA

Di sisi transaksi modal dan finansial (KA), aliran modal asing relatif terbatas dan berfluktuasi. Dari sisi jumlah, akumulasi aliran modal relatif stabil dari tahun 2000 sampai dengan 2008 (Grafik 4). Peningkatan cukup signifikan terjadi setelah tahun 2009 sejalan dengan perbaikan ekonomi domestik sehingga aliran modal portofolio dan PMA cukup besar (Grafik 6). Namun demikian, peranan aliran modal portofolio secara umum masih cukup dominan dan berpengaruh secara keseluruhan. Dengan kondisi instrumen transaksi valuta asing dan tingkat kedalaman pasar valas domestik yang relatif dangkal, sentimen negatif jangka pendek yang berpengaruh pada aliran modal asing kerap berpengaruh pada nilai tukar.

Aliran modal asing mengalir deras ke negara emerging market paska krisis keuangan global 2008 yang dipicu oleh permasalahan subprime mortgage di AS. Krisis yang kemudian menyebar ke kawasan Eropa dan seluruh dunia memaksa negara-negara maju yang terkena paling dampak krisis tersebut untuk melakukan quantitative easing yang disertai dengan ekspansi fiskal untuk menyelamatkan perekonomian masing-masing. Likuiditas global yang berlimpah selanjutnya mengalir ke negara-negara emerging yang kinerja ekonominya tetap baik. Namun, aliran modal tersebut menjadi sangat volatile oleh karena tingginya faktor ketidakpastian pemulihan ekonomi global.

Aliran modal asing yang masuk ke Indonesia juga cenderung terus meningkat, dan sebagian besar merupakan aliran modal jangka pendek (Portfolio Investment). Setelah krisis 2008 aliran modal mengalir deras ke Indonesia dimana dalam periode inflows antara triwulan III/2009 sampai dengan triwulan III/2011 tercatat net capital inflows sebesar USD49,7 miliar - sebesar USD29 miliar (58\%) merupakan portfolio investment (PI). Aliran modal tersebut mendorong apresiasi rupiah sebesar 18\% dari level Rp10.500 per USD (Juni 2009) ke level Rp8.600 (Juni 2011). Dana tersebut yang diinvestasi di pasar keuangan rupiah juga mendorong kenaikan harga aset keuangan rupiah yang antara lain tercermin pada peningkatan IHSG dan penurunan yield SUN. 


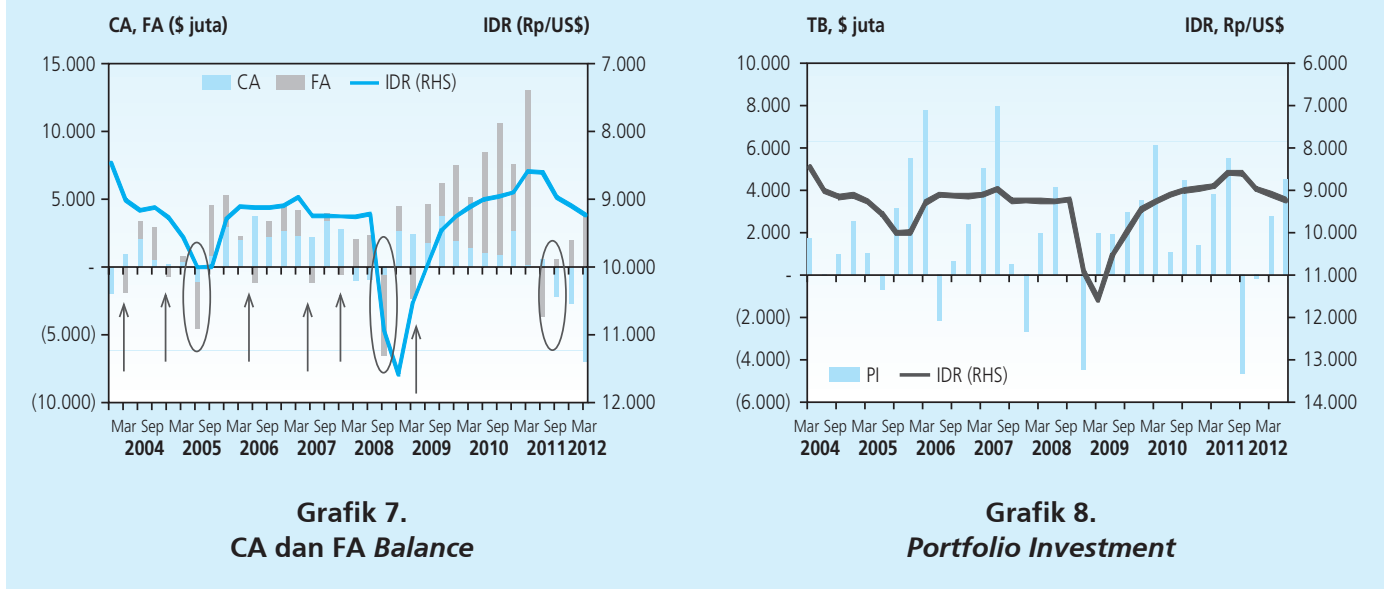

Beberapa kajian mengenai aliran modal asing ke Indonesia paska krisis global 2008 pernah dilakukan, antara lain oleh Agung et al (2011) yang mengkonfirmasi peningkatan aliran modal asing ke Indonesia didominasi oleh dana jangka pendek (PI). Implikasinya, aliran modal asing ke Indonesia cenderung semakin volatile yang ditunjukkan oleh koefisien variasi PI yang meningkat paska krisis global 2008. Penelitian ini secara komprehensif membedah aliran modal asing ke Indonesia baik dalam bentuk FDI, PI, maupun Other Investment (utang LN). Aliran PI secara langsung mempengaruhi supply dan demand di pasar valas sehingga sangat signifikan mempengaruhi pergerakan nilai tukar rupiah.

Agung et al (2011) lebih jauh lagi juga menelaah lebih dalam menurut outlet investasinya (SUN, saham dan SBI). Investasi pada SBI merupakan investasi yang paling volatile (bersifat temporer atau tidak persisten) dan semakin volatile paska krisis 2008 sehingga tidak mengherankan apabila BI mewajibkan investor SBI untuk memegangnya minimal 6 bulan. Aliran modal asing di pasar saham juga termasuk volatile dimana volatilitasnya juga cenderung meningkat paska krisis 2008. Berbeda dengan investasi asing pada SBI dan saham, investasi asing pada SUN justru semakin persisten. Hal ini sejalan dengan kinerja perekonomian Indonesia yang tetap baik termasuk defisit fiskal yang relatif terjaga ditengah memburuknya perekonomian global.

Terkait dengan durasi, Agung et al (2011) juga menunjukkan bahwa secara keseluruhan aliran modal asing yang masuk ke Indonesia memiliki durasi investasi yang relatif pendek (1-2 bulan). Nugroho (2010) dalam penelitian sebelumnya juga telah menunjukkan bahwa durasi modal asing yang diinvestasikan di Indonesia relatif pendek (1 bulan). Hal ini sejalan dengan sebagian besar perilaku pihak asing dalam melakukan transaksi di pasar valas yang pada umumnya adalah berkarakter sebagai trader, yaitu melakukan transaksi jual dan beli valas dalam jangka pendek untuk memperoleh exchange rate gain. 
Karakteristik yang juga menonjol dari aliran modal asing adalah dampaknya yang asimetrik terhadap nilai tukar. Agung et al (2011) membuktikan bahwa aliran modal keluar berdampak lebih besar terhadap nilai tukar rupiah dan memiliki durasi yang lebih panjang, dibandingkan dampak aliran modal masuk. Sugeng et al (2009) juga membuktikan bahwa dampak capital outflows (peningkatan demand valas atau penurunan supply valas dari pelaku luar negeri) berdampak lebih besar terhadap depresiasi rupiah dibandingkan dampak capital inflows terhadap apresiasi rupiah. Sugeng (2009) juga membuktikan bahwa pengaruh transaksi valas yang dilakukan pihak asing berdampak lebih signifikan terhadap nilai tukar rupiah dibandingkan dampak transaksi valas yang dilakukan pelaku domestik.

Bagian ini telah menguraikan kondisi aktual dari pasar, perilaku agen, dan kondisi eksternal dari perekonomian Indonesia. Bagian selanjutnya akan mengkonfrontasikan kondisi real ini dengan hasil estimasi model empiris.

\subsection{Hasil Estimasi}

Hasil uji empiris (Tabel 1) menunjukkan bahwa aliran modal baik aliran masuk maupun keluar berdampak signifikan terhadap nilai tukar rupiah, Namun, pengaruhnya tidak simetrik dimana aliran modal keluar berdampak lebih kuat dibanding aliran modal masuk. Hasil estimasi menunjukkan setiap terjadi aliran modal keluar terlebih capital reversal sebesar USD100 juta akan mengakibatkan nilai tukar rupiah terdepresiasi sebesar Rp3,2 pada hari yang sama. Dampak depresiasi rupiah akibat aliran modal keluar tersebut tidak berhenti pada hari itu saja, namun berlanjut di periode berikutnya dengan besaran depresiasi yang semakin mengecil seperti ditunjukkan oleh impulse response function pada Grafik 9 di bawah. Dampak akumulatif dari aliran modal keluar sebesar USD100 juta tersebut dapat mengakibatkan depresiasi rupiah sebesar Rp16 dalam waktu sekitar 15 hari. Sementara itu, dampak aliran modal masuk sebesar

\begin{tabular}{|c|c|}
\hline \multicolumn{2}{|c|}{$\begin{array}{c}\text { Tabel } 1 \text { Hasil Estimasi Pengaruh Capital Flows } \\
\text { terhadap Nilai Tukar }\end{array}$} \\
\hline Dependent Var. & Nominal IDR \\
\hline $\begin{array}{l}\text { Independent Var.: } \\
\text { Constant } \\
\text { Capital Outflows } \\
\text { Capital Inflows } \\
\text { Bl's SUN operation } \\
\text { Lag Dep. Var. (-1) } \\
\text { Lag Dep. Var. (-2) } \\
\text { R-squared }\end{array}$ & $\begin{array}{c}-48,0939 \\
0,0322 * * \\
-0,0301 * \\
0,0036 \\
0,8023 * * * \\
0,2033 * \\
0,289\end{array}$ \\
\hline Sample (adjusted): 1/0 & \\
\hline
\end{tabular}

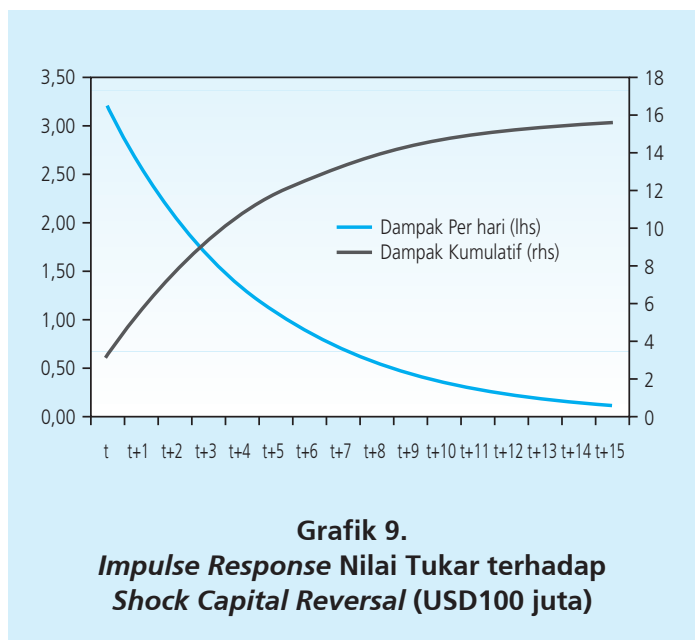


USD100 juta berdampak pada apresiasi rupiah hanya sebesar Rp3 rupiah dan baru terjadi 3 hari kemudian (lag 3 hari).

Operasi moneter BI menggunakan SUN menunjukkan arah yang sesuai ekspektasi, yaitu kenaikan pembelian SUN oleh BI ekspansi likuiditas berdampak depresiatif terhadap nilai tukar. Namun, dampak operasi BI tersebut kurang signifikan. Sementara itu, level nilai tukar pada periode sebelumnya sangat menentukan level nilai tukar rupiah pada saat ini.

Aliran modal asing yang masuk ke Indonesia dalam hal ini portfolio investment pada umumnya ditempatkan pada SUN (obligasi pemerintah jangka panjang, sampai dengan 30 tahun), SPN (surat perbendaharaan negara berjangka pendek), SBI dan saham. Penelitian yang lebih mendalam menunjukkan bahwa pengaruh aliran modal masuk yang ditempatkan pada outlet-outlet investasi tersebut memiliki pengaruh yang berbeda. Secara umum aliran modal asing baik dalam bentuk gross inflow, gross outflow maupun net flows yang ditanamkan pada seluruh outlet investasi yang disebutkan di atas, kecuali gross inflows pada saham, berdampak signifikan terhadap nilai tukar rupiah. Capital inflows mendorong apresiasi rupiah dan capital outflows mendorong depresiasi rupiah, sementara net inflows (inflows dikurangi outflows) mendorong apresiasi rupiah.

Berdasarkan hasil estimasi model (lihat Tabel 2), aliran modal asing pada SPN memberikan dampak yang paling besar terhadap nilai tukar rupiah. Hal ini tercermin pada koefisien regresinya yang relatif lebih besar dibandingkan aliran modal asing pada outlet lainnya. Setelah SPN, pengaruh aliran modal asing pada SUN juga memberikan pengaruh yang besar, dan selanjutnya diikuti oleh aliran investasi asing pada saham dan SBI. Selain itu, hasil estimasi juga secara umum mengindikasikan pengaruh asimetrik antara aliran masuk dan keluar dimana koefisien regresi untuk aliran keluar lebih besar daripada koefisien aliran masuk, kecuali pada investasi asing di SBI. Pada bagian selanjutnya akan diuraikan pengaruh aliran modal asing pada masing-masing outlet dan faktor-faktor lainnya pada pergerakan nilai tukar rupiah.

\begin{tabular}{|c|c|c|c|c|c|}
\hline \multicolumn{6}{|c|}{$\begin{array}{c}\text { Tabel } 2 \\
\text { Perbandingan Pengaruh Aliran Modal Asing pada Outlet Investasi terhadap Nilai Tukar Rupiah }\end{array}$} \\
\hline Variabel & & SUN & Saham & SBI & SPN \\
\hline Net Capital Flows & & $-0.0559^{* *}$ & $-0.0480^{*}$ & $-0.0289^{* *}$ & $-0.1524^{* * *}$ \\
\hline Capital Inflows & & $-0.0705^{\star}$ & -0.0554 & $-0.0424^{* *}$ & $0.2135^{\text {*ᄎ }}$ \\
\hline Capital Outflows & & $0.1295^{\star *}$ & $0.1101^{* *}$ & $0.0359^{\star *}$ & $0.2529^{\star *}$ \\
\hline \multirow[t]{3}{*}{ Net Capital Flows } & Model 1 & $-0.0180^{* *}$ & $-0.0531^{* * *}$ & $-0.0287^{*}$ & $-0.0212^{* *}$ \\
\hline & Model 2 & $-0.0290^{* * *}$ & $-0.0495^{\star * *}$ & $-0.0286^{\star *}$ & $-0.0176^{*}$ \\
\hline & Model 3 & $-0.0266^{\star * *}$ & $-0.0304^{* * *}$ & $-0.0364^{* *}$ & $-0.0223^{* *}$ \\
\hline
\end{tabular}




\section{Dampak Aliran Investasi pada SUN terhadap Nilai Tukar}

Aliran modal asing yang ditempatkan pada SUN berdampak signifikan pada pergerakan nilai tukar rupiah, baik aliran modal masuk, keluar maupun aliran modal bersih aliran modal masuk dikurangi aliran modal keluar. Sebagaimana aliran modal secara keseluruhan, aliran modal asing yang terkait dengan SUN juga berdampak asimetrik pada nilai tukar rupiah. Aliran modal keluar sebesar USD100 juta berdampak pada depresiasi rupiah sebesar Rp13 berdasarkan estimasi menggunakan model persamaan 2, atau sebesar Rp14 dengan menggunakan model persamaan 3. Sementara aliran modal masuk dalam jumlah yang sama hanya berdampak pada apresiasi rupiah sebesar Rp7.

\section{Tabel 3}

Hasil Estimasi Pengaruh Aliran Modal Asing pada SUN terhadap Nilai Tukar

\begin{tabular}{l|c|c|c}
\multicolumn{1}{c|}{ Dependent Var. } & Nominal IDR & Nominal IDR & Nominal IDR \\
Independent Var.: & $-42,7112$ & $-49,2248$ & $-54,6954$ \\
Constant & $-0,0559 * *$ & & \\
Net Capital Flows - SUN & & $-0,0705 *$ & \\
Capital Inflows - SUN & & $0,1295 * *$ & $0,1416 * *$ \\
Capital Outflows - SUN & $-0,0180 * *$ & $-0,0290 * * *$ & $-0,0266 * * *$ \\
Net Capital Flows - Others & 0,0034 & 0,0031 & 0,0031 \\
BI's SUN operation & $0,7957 * * *$ & $0,7919 * * *$ & $0,7902 * * *$ \\
Lag Dep. Var. (-1) & $0,2095 *$ & $0,2138 * *$ & $0,2159 * *$ \\
Lag Dep. Var. (-2) & 0,9966 & 0,9968 & 0,9967 \\
\hline R-squared & & & \\
\hline
\end{tabular}

Sample (adjusted): 1/04/2008 3/21/2012

Note: ${ }^{* * *},{ }^{* *}$ dan ${ }^{*}$ signifikan di level $1 \%, 5 \%$ dan $10 \%$.

Aliran modal lainnya (Net Capital Flows - Others) juga berpengaruh signifikan terhadap nilai tukar. Namun, pengaruhnya relatif lebih kecil dibandingkan aliran investasi asing pada SUN, yaitu apresiasi (depresiasi) sekitar Rp1,8 - Rp2,9 setiap terjadi aliran masuk (keluar) modal lainnya sebesar USD100 juta.

\section{Dampak Aliran Investasi pada Saham terhadap Nilai Tukar}

Aliran modal asing yang ditanamkan pada saham tidak sepenuhnya mempengaruhi nilai tukar secara signifikan. Aliran modal bersih dan aliran modal keluar mempengaruhi nilai tukar, namun aliran modal masuk tidak berpengaruh pada nilai tukar. Aliran modal keluar dari investasi saham sebesar USD100 juta akan mengakibatkan depresiasi rupiah sebesar Rp11 Rp12. Sementara aliran modal masuk bersih sebesar USD100 juta akan mendorong apresiasi rupiah sebesar Rp4,8 rupiah. 


\begin{tabular}{|c|c|c|c|}
\hline \multicolumn{4}{|c|}{$\begin{array}{l}\text { Tabel } 4 \\
\text { Hasil Estimasi Pengaruh Aliran Modal Asing pada Saham terhadap Nilai Tukar }\end{array}$} \\
\hline Dependent Var. & Nominal IDR & Nominal IDR & Nominal IDR \\
\hline \multicolumn{4}{|l|}{ Independent Var.: } \\
\hline Constant & -37.5825 & -44.8483 & -50.0494 \\
\hline Net Capital Flows - Saham & $-0.0480 *$ & & \\
\hline Capital Inflows - Saham & & -0.0554 & \\
\hline Capital Outflows - Saham & & $0.1101 * *$ & 0.1178 ** \\
\hline Net Capital Flows - Others & $-0.0531 * * *$ & $-0.0495 * * *$ & $-0.0304 * * *$ \\
\hline BI's SUN operation & 0.0032 & 0.0032 * & 0.0034 * \\
\hline Lag Dep. Var. $(-1)$ & $0.8072^{* * *}$ & $0.8024^{* * *}$ & $0.7884^{* * *}$ \\
\hline Lag Dep. Var. (-2) & 0.1975 * & $0.2030 * * *$ & $0.2174^{* * *}$ \\
\hline R-squared & 0.9967 & 0.9968 & 0.9967 \\
\hline \multicolumn{4}{|c|}{ Sample (adjusted): 12/19/2008 3/21/2012 } \\
\hline
\end{tabular}

Aliran modal lainnya secara neto (aliran masuk dikurangi aliran keluar) juga berpengaruh signifikan terhadap rupiah. Aliran modal masuk (keluar) sebesar USD100 juta akan berdampak pada apresiasi (depresiasi) antara Rp3 - Rp5,3.

\section{Dampak Aliran Investasi pada SBI terhadap Nilai Tukar}

Aliran investasi asing pada SBI sedikit berbeda dengan aliran modal asing yang ditanamkan pada outlet investasi lain. Aliran modal masuk yang diinvestasikan pada SBI berdampak pada nilai tukar secara lebih kuat, dibandingkan dampak aliran keluar modal asing dari SBI. Aliran modal masuk sebesar USD100 juta akan mendorong apresiasi rupiah sebesar Rp4,2, sementara aliran modal keluar dalam jumlah yang sama hanya mendorong depresiasi rupiah sebesar Rp3,6. Sementara itu, aliran net investasi asing pada SBI sebesar +/- USD100 juta akan mendorong apresiasi/depresiasi sebesar Rp2,9.

Aliran modal lain juga berpengaruh pada pergerakan nilai tukar rupiah. Aliran modal bersih masuk (keluar) sebesar USD100 juta akan berpengaruh pada apresiasi (depresiasi) rupiah sekitar Rp3. Hasil estimasi di atas juga menunjukkan bahwa operasi pembelian/penjualan SUN oleh BI berdampak signifikan pada nilai tukar rupiah. Pembelian SUN oleh BI sebesar Rp1000 miliar sehingga likuiditas rupiah meningkat akan mendorong depresiasi rupiah sebesar Rp18, atau sebaliknya jika BI menjual SUN. 


\begin{tabular}{|c|c|c|c|}
\hline \multicolumn{4}{|c|}{$\begin{array}{l}\text { Tabel } 5 \\
\text { Hasil Estimasi Pengaruh Aliran Modal Asing pada SBI terhadap Nilai Tukar }\end{array}$} \\
\hline Dependent Var. & Nominal IDR & Nominal IDR & Nominal IDR \\
\hline \multicolumn{4}{|l|}{ Independent Var.: } \\
\hline Constant & 8.7738 & 4.5699 & 7.8794 \\
\hline Net Capital Flows - SBI & $-0.0289 * *$ & & \\
\hline Capital Inflows - SBI & & $-0.0424 * *$ & \\
\hline Capital Outflows - SBI & & $0.0359 * *$ & 0.0338 ** \\
\hline Net Capital Flows - Others & $-0.0287 *$ & $-0.0286 * *$ & $-0.0264 * *$ \\
\hline BI's SUN operation & $0.0182 * * *$ & $0.0185^{* * *}$ & $0.0183^{* * *}$ \\
\hline Lag Dep. Var. (-1) & $0.7800 * * *$ & $0.7795^{* * *}$ & $0.7835^{* * *}$ \\
\hline Lag Dep. Var. (-2) & $0.2189^{* *}$ & 0.2199 ** & $0.2155^{* *}$ \\
\hline R-squared & 0.9722 & 0.9724 & 0.9722 \\
\hline
\end{tabular}

\section{Dampak Aliran Investasi pada SPN terhadap Nilai Tukar}

Sebagaimana aliran modal asing yang ditempatkan pada SUN, aliran modal asing pada SPN juga berdampak signifikan pada nilai tukar rupiah, baik aliran modal masuk, keluar maupun aliran modal bersih - aliran modal masuk dikurangi aliran modal keluar. Aliran modal keluar sebesar USD100 juta berdampak pada depresiasi rupiah sebesar Rp24 - Rp25. Sebaliknya, aliran modal masuk dalam jumlah yang sama hanya berdampak pada apresiasi rupiah sebesar Rp21. Sementara itu, aliran modal masuk (keluar) bersih pada SPN sebesar USD100 juta akan mendorong apresiasi (depresiasi) rupiah sebesar Rp15.

\begin{tabular}{|c|c|c|c|}
\hline \multicolumn{4}{|c|}{$\begin{array}{c}\text { Tabel } 6 \\
\text { Hasil Estimasi Pengaruh Aliran Modal Asing pada SPN terhadap Nilai Tukar }\end{array}$} \\
\hline Dependent Var. & Nominal IDR & Nominal IDR & Nominal IDR \\
\hline \multicolumn{4}{|l|}{ Independent Var.: } \\
\hline Constant & 2.2907 & -6.6035 & -26.5026 \\
\hline Net Capital Flows - SPN & $-0.1524^{* * *}$ & & \\
\hline Capital Inflows - SPN & & $-0.2135 * *$ & \\
\hline Capital Outflows - SPN & & 0.2529 ** & 0.2385 ** \\
\hline Net Capital Flows - Others & $-0.0212 * *$ & $-0.0176 *$ & $-0.0223 * *$ \\
\hline BI's SUN operation & $0.0187^{* * *}$ & $0.0186^{* * *}$ & $0.0187^{* * *}$ \\
\hline Lag Dep. Var. (-1) & $0.8107^{* * *}$ & $0.8333^{* * *}$ & $0.8236^{* * *}$ \\
\hline Lag Dep. Var. (-2) & 0.1889 ** & 0.1673 * & 0.1789 ** \\
\hline R-squared & 0.9734 & 0.9724 & 0.9726 \\
\hline \multicolumn{4}{|c|}{ Sample (adjusted): 11/25/2009 3/21/2012 } \\
\hline
\end{tabular}


Hasil estimasi di atas juga menunjukkan bahwa operasi pembelian/penjualan SUN oleh BI berdampak signifikan pada nilai tukar rupiah. Pembelian SUN oleh BI sebesar Rp1000 miliar sehingga likuiditas rupiah meningkat akan mendorong depresiasi rupiah sebesar Rp19.

\section{Dampak Kinerja Current Account terhadap Nilai Tukar}

Hasil estimasi model threshold dengan menggunakan model TAR menghasilkan beberapa nilai threshold terbaik untuk model menggunakan AR-4, AR-5 dan AR-6. Ketiga model menunjukkan adanya threshold level CAdeficit, dan apabila defisitCA melewati threshold tersebut, maka efek ke perubahan nilai tukar menjadi cukup besar dan signifikan. Sebaliknya, level CA defisit yang relatif rendah atau di bawah threshold cenderung dapat ditoleransi pasar tanpa menimbulkan gejolak nilai tukar.

Threshold untuk model pertama (AR-4) adalah sebesar USD980 juta, sementara model kedua (AR-5) adalah sebesar USD810 juta. Untuk model ketiga (AR-6) threshold defisit neraca berjalan adalah sebesar USD730 juta.

Hasil estimasi dengan periode Januari 2008 s.d. Juni 2012 menunjukkan adanya threshold level CA sebesar defisit USD980 Juta (bulanan) dengan lag efek 4 bulan. Grafik impulse response menunjukkan bahwa apabila terjadi shock level CA melewati threshold atau $\leq$ USD-980 juta (bulanan), maka dampak maksimum ditransmisikan ke nilai tukar 4 bulan berikutnya yaitu depresiasi sebesar 12,7\% (m.o.m), dengan efek kumulatif ke nilai tukar dalam 1 tahun yaitu depresiasi sebesar 13\% (grafik 10 dan 11).

Sementara itu, jika level CA belum melewati threshold, maka efek ke perubahan nilai tukar relatif kecil. Hasil impulse response menggunakan shock level CA sebesar defisit USD500 juta (bulanan) menunjukkan efek ke perubahan nilai tukar yang relatif kecil dengan efek kumulatif dalam 1 tahun sebesar 0,4\%.

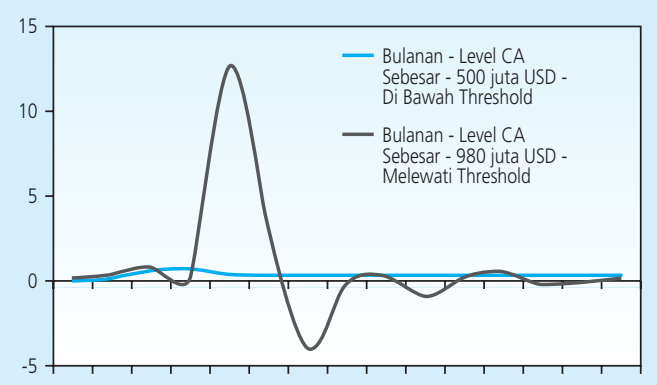

to $t+1 \quad t+2 \quad t+3 \quad t+4 \quad t+5 \quad t+6 \quad t+7 \quad t+8 \quad t+9 t+10 t+11 t+12 t+13 t+14$

Grafik 10.

Impulse Response Penurunan CA terhadap Nilai Tukar (Defisit USD980 juta)

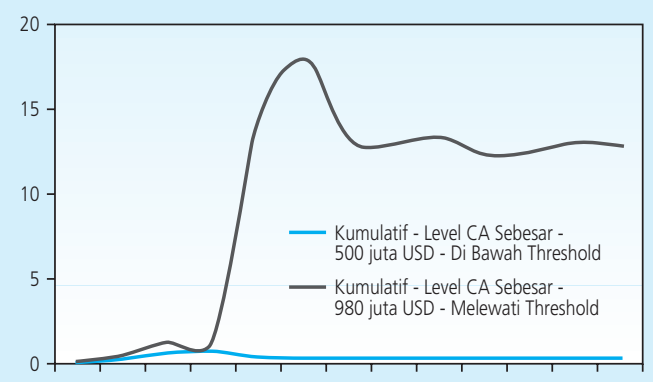

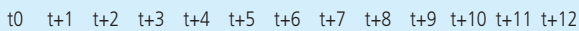

Grafik 11.

Kumulatif Impulse Response Penurunan CA terhadap Nilai Tukar (Defisit USD980 juta) 
Model kedua AR-5, juga menggunakan rentang periode yang sama yakni Januari 2008 sampai dengan Juni 2012 menunjukkan adanya threshold level CA sebesar defisit USD810 Juta (bulanan) dengan efek tunda 4 bulan. Grafik impulse response menunjukkan bahwa apabila terjadi shock defisit CA melewati threshold atau $\leq$ USD-810 juta (bulanan), maka dampak maksimum ditransmisikan ke nilai tukar 4 bulan berikutnya yaitu depresiasi sebesar 32\% (m.o.m), dengan efek kumulatif ke nilai tukar dalam 1 tahun yaitu depresiasi sebesar 29\% (grafik 12 dan 13). Sementara itu, jika level defisit CA belum melewati threshold, maka efek ke perubahan nilai tukar relatif kecil. Hasil impulse response menggunakan shock defisit CA sebesar USD500 juta (bulanan) menunjukkan efek ke perubahan nilai tukar yang relatif kecil dengan efek kumulatif dalam 1 tahun sebesar 0,3\%.

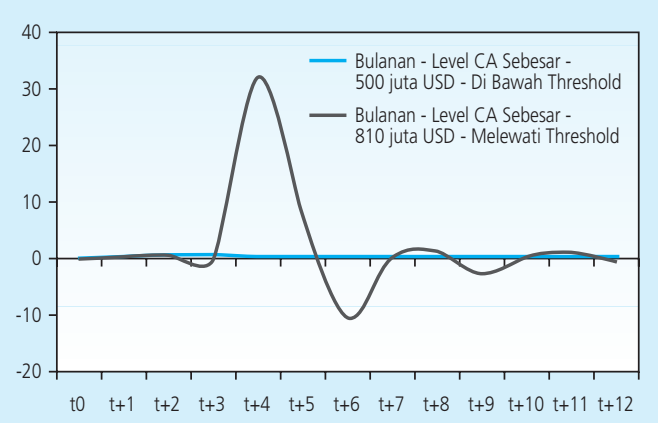

Grafik 12.

Impulse Response Penurunan CA terhadap Nilai Tukar (Defisit USD810 juta)

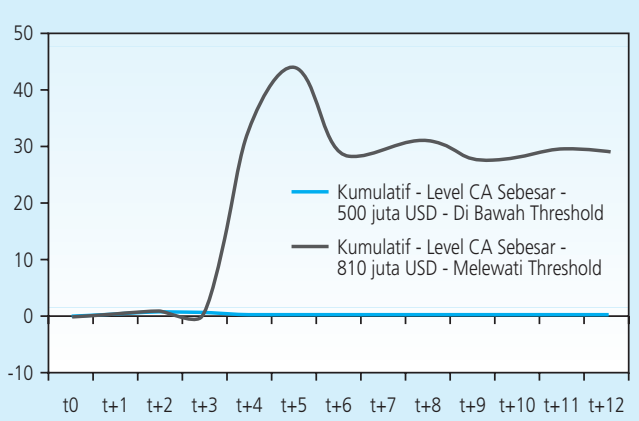

Grafik 13.

Kumulatif Impulse Response Penurunan CA terhadap Nilai Tukar (Defisit USD810 juta)

Untuk model ketiga dengan threshold defisit neraca berjalan sebesar USD730 juta, grafik impulse response menunjukkan bahwa apabila terjadi shock defisit CA melewati threshold atau $\leq$ USD-730 juta (bulanan), maka dampak maksimum ditransmisikan ke nilai tukar 4 bulan berikutnya yaitu depresiasi sebesar 4,4\% (m.o.m), dengan efek kumulatif ke nilai tukar dalam 1 tahun yaitu depresiasi sebesar 3,3\% (grafik 14 dan 15). Sementara itu, jika level CA belum melewati threshold, maka efek ke perubahan nilai tukar relatif kecil. Hasil impulse response menggunakan shock defisit CA sebesar USD500 juta (bulanan) menunjukkan efek ke perubahan nilai tukar yang relatif kecil dengan efek kumulatif dalam 1 tahun sebesar 0,2\%. 


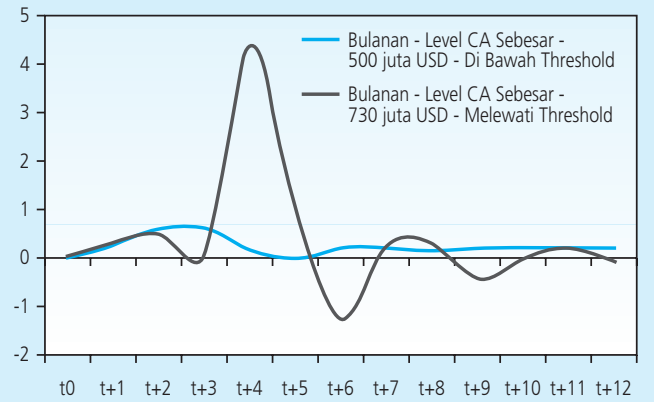

Grafik 14.

Impulse Response Penurunan CA terhadap Nilai Tukar (Defisit USD730 juta)

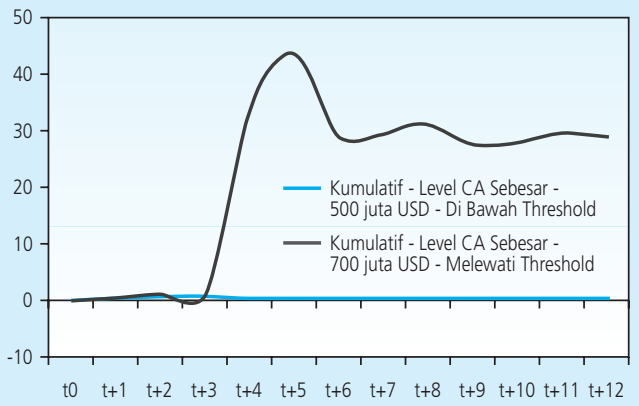

Grafik 15.

Kumulatif Impulse Response Penurunan CA terhadap Nilai Tukar (Defisit USD730 juta)

\section{Determinan dan Probabilitas Terjadinya Sudden Stop}

Untuk menangkap perilaku capital reversal, paper ini mengaplikasikan model probit dan bagian ini menguraikan hasil estimasinya. Model probit ini mengetimasi probabilitas terjadinya capital reversal dengan melihat perubahan beberapa faktor penentu seperti indeks harga saham global (menggunakan indeks Dow Jones Industrial Average atau DJIA), faktor risiko global (indeks VIX), indeks harga saham di pasar saham domestik (IHSG) dan yield SUN.

Dalam kajian perilaku ini digunakan 3 varian model ekonometrik untuk menjelaskan perilaku capital reversal. Persamaan pertama menggunakan DJIA dan yield SUN sebagai variabel penjelas. Hasil estimasi menunjukkan bahwa apabila indeks harga saham global menurun atau memburuk maka probabilitas terjadinya capital reversal cenderung meningkat. Hal ini dapat disebabkan oleh ekspektasi terjadinya contagion effect pada harga saham domestik, sehingga mendorong investor asing untuk menarik keluar investasinya dari Indonesia.

Imbal hasil SUN juga berpengaruh pada capital reversal dengan arah negatif dimana penurunan yield SUN (merepresentasikan kenaikan harga SUN) cenderung meningkatkan probabilitas terjadinya capital reversal. Harga SUN yang meningkat (yield SUN menurun), terlebih apabila sudah overvalued, akan mendorong investor untuk melakukan profit taking dengan melepas SUN yang dimilikinya. Hal ini sejalan dengan karakter investasi portofolio jangka pendek yang sangat memperhatikan return dengan melakukan pembelian pada saat harga aset menurun (buy low) dan menjual pada saat harga tinggi (sell high). Pelepasan SUN oleh investor asing identik dengan capital reversal.

Persamaan kedua menggunakan yield SUN dan indeks risiko (VIX) sebagai faktor determinan. Pengaruh yield SUN terhadap capital reversal relatif sama dengan penjelasan di atas. Sementara itu, indeks risiko juga berpengaruh signifikan terhadap kecenderungan 
terjadinya capital reversal. Kondisi risiko yang memburuk tercermin pada kenaikan indeks VIX akan meningkatkan probabilitas terjadinya capital reversal.

\begin{tabular}{|c|c|c|c|}
\hline \multicolumn{4}{|c|}{$\begin{array}{c}\text { Tabel } 7 \\
\text { Hasil Estimasi Probabilitas Sudden Reversal Akibat Perubahan Return Investasi dan Faktor Risiko }\end{array}$} \\
\hline Dependent Var. & Prob. Cap. Reversal & Prob. Cap. Reversal & Prob. Cap. Reversal \\
\hline $\begin{array}{l}\text { Independent Var.: } \\
\text { Constant } \\
\text { Global Stock Price: DJIA } \\
\text { Yield SUN } \\
\text { IHSG } \\
\text { Risk Factor: VIX } \\
\text { Lag Dep. Var. (-1) } \\
\text { Lag Dep. Var. (-2) }\end{array}$ & $\begin{array}{l}2.0073^{* * *} \\
-0.0006^{* * *} \\
-0.1156^{*}\end{array}$ & $\begin{array}{l}-0.3944 \\
-0.1315^{* *} \\
0.0193^{* *} \\
0.6607^{* * *} \\
0.4164^{*}\end{array}$ & $\begin{array}{l}0.0004^{* * *} \\
0.0238^{* * *} \\
0.6355^{* * *} \\
0.3841^{* * *}\end{array}$ \\
\hline R-squared & 0.1254 & 0.1110 & 0.1171 \\
\hline
\end{tabular}

Persamaan ketiga menggunakan indeks risiko (VIX) dan indeks harga saham domestik (IHSG) sebagai faktor determinan. Baik indeks VIX maupun IHSG berpengaruh signifikan terhadap capital reversal. Kenaikan indeks risiko dan harga saham cenderung meningkatkan probabilitas terjadinya capital reversal.

\section{KESIMPULAN}

Aliran modal asing terutama modal jangka pendek yang diinvestasikan pada aset keuangan rupiah berpengaruh signifikan terhadap nilai tukar rupiah. Aliran modal masuk akan mendorong apresiasi rupiah terhadap US dollar, dan sebaliknya, aliran modal keluar berdampak pada depresiasi rupiah. Secara umum aliran modal keluar berdampak lebih besar terhadap nilai tukar rupiah dalam arti depresiasi yang ditimbulkan relatif lebih besar dibandingkan apresiasi yang terjadi pada saat terjadi aliran modal masuk dengan pengecualian aliran modal yang diinvestasikan dalam SBI.

Paper ini menganalisa perilaku aliran modal lintas jenis investasi yakni Surat Utang Negara (SUN), Surat Perbendaharaan Negara (SPN), saham, dan investasi lainnya. Kami menemukan bahwa nilai tukar rupiah relatif lebih sensitif terhadap perubahan aliran modal asing pada SUN dibandingkan terhadap perubahan aliran modal pada Saham dan SBI. Hal ini cukup beralasan mengingat investor di pasar saham dapat melakukan switching antar saham yang pergerakan harganya bervariasi untuk memaksimalkan profitnya. Dengan demikian, pelepasan saham oleh investor asing tidak selalu berdampak pada capital reversal. Hal ini berbeda dengan 
investasi pada SUN yang pergerakan harga masing-masing seri cenderung searah, sehingga investor hanya memiliki 2 pilihan yaitu investasi di SUN atau menarik modalnya keluar (capital reversal). Sementara itu, investasi pada SBI lebih relatif lebih terbatas dan lebih terkait dengan manajemen likuiditas. Selain itu, SBI memiliki jatuh tempo yang sangat pendek (kurang dari 1 tahun), sehingga investor otomatis harus melepas SBI pada saat jatuh tempo, dan upaya untuk memperoleh kembali di pasar perdana dan pasar sekunder dihadapkan pada suplai yang terbatas. Nilai tukar pada dasarnya juga sangat sensitif terhadap aliran modal asing pada SPN, namun mengingat volumenya yang terbatas maka pengaruhnya pada perubahan nilai tukar juga terbatas.

Perilaku atau keputusan investor asing untuk investasi di Indonesia atau di luar Indonesia dipengaruhi oleh tingkat return investasi dan faktor risiko. Hal ini tercermin pada hasil estimasi probabilitas terjadinya capital reversal yang dipengaruhi secara signifikan oleh harga aset keuangan global (DJIA) dan faktor risiko global (VIX), serta tingkat return investasi dalam aset rupiah (IHSG dan yield SUN). Yield SUN berpengaruh signifikan dan relatif besar terhadap probabilitas terjadinya capital reversal, sepanjang risiko global dalam kondisi yang kondusif.

Aliran dana lain yang juga berpengaruh signifikan pada nilai tukar adalah aliran modal yang bersumber dari transaksi CA. Bahkan, kinerja CA yang memburuk dan melewati threshold tertentu dapat memberikan dampak yang berlipat terhadap depresiasi nilai tukar rupiah. Hasil estimasi menunjukkan bahwa apabila defisit CA melebihi threshold defisit USD980 juta (kurang lebih ekuivalen $2 \%$ dari GDP), nilai tukar akan terdepresiasi sebesar 12,7\% (m-o-m) dengan efek tunda 4 bulan.

Dari temuan empiris di atas, paper ini memberikan beberapa rekomendasi kebijakan untuk menjaga stabilitas nilai tukar rupiah, pertama, meningkatkan pengawasan terhadap investasi asing pada aset keuangan rupiah, terutama pada SUN dan saham. Kedua, meningkatkan pengawasan terhadap perkembangan IHSG, imbal hasil SUN, dan perkembangan indikator risiko global untuk memprediksi terjadinya capital reversal secara keseluruhan. Ketiga, melakukan berbagai upaya untuk memperbaiki kinerja neraca berjalan (CA) dan mencegah defisit neraca berjalan melampaui batas threshold. Keempat, dalam menjaga stabilitas nilai tukar pada saat terdeteksi potensi capital reversal, maka perlu menjaga cadangan devisa yang cukup untuk melakukan intervensi pada pasar valas. 


\section{DAFTAR PUSTAKA}

Agung, Juda, M. Noor Nugroho and Yanfitri (2011), "Arus Modal Jangka Pendek di Indonesia Pasca Krisis Global: Karakteristik, Prospek dan Respon Kebijakan", Bank Indonesia Working Paper, Juni 2011.

Berg, Andrew, and Pattillo Catherine (1999)" Are Currency Crisiss Predictable? A Test" IMF Economic Review, Jun 1999; 46,2.

Calderon, Cesar, Alberto Chong and Norman Loayza, 2000." Determinant of Current Account Deficit in Developing Countries," The World Bank Policy Research Working Paper, No. 2398.

Chinn, Menzie D., and Eswar S. Prasad.2003. " Medium-Term Determinants of Current Account in Industrial and Developing Countries: An Empirical Exploration" Journal of International Economics, Vol. 59, pp 47-76.

Calvo G (1998)" Capital Flows And Capital - Market Crises: The Simple Economics Of Sudden Stops" Journal of Applied Economics 1:35-54.

Edwards, Sebastian (2004), " Financial Opennes, Sudden Stops and Current Account Reversals" National Bureau of Economic Research, Working Paper 10277, January 2004.

Edwards, Sebastian (2005)," Capital Controls, Sudden Stops and Current Account Reversals" National Bureau of Economic Research, Working Paper 11170, 2005.

Frankel, Jeffrey A., and Andrew K. Rose, (1996)" Currency Crashes In Emerging Markets: An Empirical Treatment" Journal Of International Economics, Vol. 41 (nov), pp. 351-66.

Hansen, Bruce (1999), "Threshold Effects in Non-Dynamic Panels: Estimation, Testing, and Inference," Journal of Econometrics, Vol. 93, No. 2. pp. 345-68.

Hutchinson M, Noy I (2006)," Sudden Stops And The Mexican Wave: Currency Crisis, Capital Flows Reversal And Output Loss In Emerging Markets" Journal Of Development Economics 79(1):225-249, 2006.

Kaminsky, Graciela, Saul Lizondo, and Carmen Reinhart, 1998" Leading Indicators Of Currency Crisis" Staff Papers, IMF, Vol 45 (March) pp.1-48.

Khan, Mohsin S., and Senhaji Abdelhak S.2001" Threshold Effects In The Relationship Between Inflation And Growth", IMS Staff Papers, Vol. 48 No.1. 
Nugroho, M. Noor (2010), "Perilaku Aliran Dana Jangka Pendek Asing dan Pengaruhnya pada Nilai Tukar Rupiah", Bank Indonesia Working Paper, Juni 2010.

Radelet S, Sachs J (1998) The East Asian financial crisis: diagnosis, remedies, prospects" Brooking Paper, economic Article 1:147-212.

Rodrik D, Velasco A(1999)" Short Term Capital Flows" National Bureau of Economic Research, Working Paper 7364, 1999.

Rudi Dornbusch, Ilan Goldfajn, dan Rodrigo Valdes. 1995"Currency Crisis And Collaps", Brookings Papers on Economic Activity, pp 219-70.

Sachs, Jeffrey, Aaron Tornell, and Andres Velasco, 1996" Financial Crisis In Emerging Markets: The Lessons From 1995," Brooking Papers On Economic Activity:1, Brooking Institution, pp.147-215.

Sahminan, Ibrahim, Yanfitri. 2009." Determinants and Sustainabality Indonesia's Current Account Balance". Working Paper No. WP/09/2009. Bank Indonesia.

Stahn Kerstin,2006" Has The Impact Of Key Determinants Of German Exports Changed? Results From Estimations Of Germany's Intra Euro-Area And Extra Euro-Area Exports" Deutsche Bundesbank, Discussion Paper Series 1: Economic Studies No. 07/2006.

Sugeng, M. Noor Nugroho, Ibrahim and Yanfitri (2009), "Dampak Dinamika Penawaran dan Permintaan Valuta Asing Terhadap Nilai Tukar Rupiah dan Perekonomian", Bank Indonesia Working Paper, Juni 2009.

Sula, Ozan (2010)" Surges and Sudden Stops of Capital Flows to Emerging Markets", Open Economic Rev (2010) 21:589-605. 